\title{
Keabsahan Keadaan Solven Debitor sebagai Dasar Pertimbangan dalam Perkara Kepailitan
}

\author{
Clarita Stefanie, R. Kartikasari, Artaji \\ Clarita17001@mail.unpad.ac.id \\ Universitas Padjadjaran
}

\begin{abstract}
Keywords: $\quad$ Abstract
Bankruptcy; This article will discuss the basic considerations of the judge in considering the debtor's Insolvency Test; solvent condition as the reason for rejecting the bankruptcy case. This article also provides Principle of an explanation that the consideration of debtor solvent conditions as the implementation Balance. $\quad$ of the principle of balance in the examination of bankruptcy cases is an essential thing to resolve the problems that occur in the Bankruptcy Law in order to create legal certainty for the parties The research method used in this article is a normative legal research method that is descriptive analytical, with the application of a normative juridical approach, by observing secondary data legal materials, with data collection techniques through document studies, with library analysis. The results of the article indicate that Judges must apply the principle of balance by taking into account the debtor's solvent condition in examining Bankruptcy cases in order to protect the interests of the parties and the interests of the business community.
\end{abstract}

Kata Kunci:

Kepailitan; Insolvency Test; Prinsip Keseimbangan.

\begin{abstract}
Abstrak
Penelitian ini akan membahas mengenai dasar pertimbangan hakim dalam mempertimbangkan mengenai keadaan solven Debitor sebagai alasan penolakan perkara Kepailitan. Penelitian ini juga memberikan penjelasan bahwa pertimbangan keadaan solven Debitor sebagai implementasi asas keseimbangan dalam pemeriksaan perkara kepailitan, merupakan suatu hal yang esensial guna menyelesaikan problematika yang terjadi dalam Undang-Undang Kepailitan demi mewujudkan kepastian hukum bagi para pihak. Metode penelitian yang digunakan dalam penelitian ini adalah metode penelitian hukum normatif yang bersifat deskriptif analitis, dengan penerapan metode pendekatan yuridis normatif, dengan melakukan pengamatan terhadap bahan-bahan hukum data sekunder, dengan teknik pengumpulan data melalui studi dokumen, dengan analisis kepustakaan. Hasil penelitian menunjukkan bahwa Hakim haruslah menerapkan asas keseimbangan dengan turut mempertimbangkan keadaan solven Debitor dalam memeriksa perkara Kepailitan guna melindungi kepentingan para pihak serta kepentingan masyarakat bisnis.
\end{abstract}

Copyright $\odot 2022$ Clarita Stefanie, R. Kartikasari, Artaji.

Published in Media Iuris. Published by Universitas Airlangga, Magister Ilmu Hukum.

\section{Pendahuluan}

Dunia bisnis tentunya tidak terlepas pada timbulnya sengketa antarpelaku usaha. Para pelaku usaha yang cenderung bergerak cepat dalam menyesuaikan diri dengan keadaan pasar yang dinamis membutuhkan suatu sarana penyelesaian atas sengketa yang dialami secara cepat. Lembaga kepailitan merupakan salah satu alternatif penyelesaian sengketa popular 
yang sering ditempuh oleh para pelaku usaha untuk menyelesaikan sengketa, terkhususnya utang-piutang.

Tujuan terbentuknya Undang-Undang Kepailitan pada dasarnya untuk memberikan jalur penyelesaian sengketa utang piutang yang berkeadilan kepada seluruh pihak yang bersengketa. Hal ini dapat terlihat pada implementasi prinsip Pari Passu Pro Rata Parte dan prinsip Paritas Creditorium dalam Undang-Undang Kepailitan yang diharapkan akan memberikan kepastian hukum dan perlindungan bagi Kreditor. Selain menyediakan sarana bagi Kreditor, Undang-Undang Kepailitan juga memberikan alternatif bagi Debitor membayarkan utangnya kepada Kreditor. Hal ini direalisasikan dengan adanya asas keberlangsungan usaha sebagai norma dasar dalam Hukum Kepailitan.

Asas keberlangsungan usaha turut diterapkan dalam mekanisme Permohonan Pailit sebagaimana yang ada pada pasal 104 ayat (1) UndangUndang 37 tahun 2004 tentang Kepailitan dan Penundaan Kewajiban Pembayaran Utang (selanjutnya disebut Undang-Undang Kepailitan) yang pada intinya menyatakan bahwa keberlangsungan usaha Debitor yang telah dinyatakan pailit pada dasarnya tetap dapat dilaksanakan oleh Kurator. Hal serupa juga terdapat dalam Pasal 104 ayat (2), Pasal 178 ayat (2), Pasal 179 ayat (1) dan Pasal 184 ayat (2) Undang-Undang Kepailitan. Dengan demikian, penerapan asas keberlangsungan usaha dalam mekanisme Permohonan Pailit hanya terdapat pada proses pemberesan harta pailit saja. Adapun penerapan asas keberlangsungan usaha ini pada dasarnya mencerminkan keadaan keuangan dari Debitor itu sendiri. Undang-Undang Kepailitan sendiri tidak mengisyaratkan adanya pertimbangan dari keadaan Debitor sebagai syarat Permohonan Pailit dan hanya memberikan patokan dalam hal dikabulkannya Permohonan Pailit yang telah memenuhi unsur Pasal 2 ayat (1) jo. Pasal 8 ayat (4) Undang-Undang Kepailitan semata. Hal ini tentunya menimbulkan celah kerugian bagi Debitor dengan kondisi finansial yang masih dalam keadaan mampu (solven) untuk mudah dinyatakan pailit.

Lebih lanjut, penerapan asas keberlangsungan usaha juga turut diterapkan dalam mekanisme Permohonan PKPU yang tercermin pada syarat pengajuan 
Permohonan PKPU pada Pasal 222 ayat (3) Undang-Undang Kepailitan yang menyatakan bahwa Kreditor yang memperkirakan bahwa Debitor tidak dapat melanjutkan membayar utangnya yang sudah jatuh waktu dan dapat ditagih. Permasalahan kembali terjadi ketika Undang-Undang Kepailitan tidak mengatur mengenai acuan yang jelas dalam menentukan keadaan Debitor sebagaimana yang dikehendaki oleh Pasal 222 ayat (3) Undang-Undang Kepailitan, mengingat pemeriksaan perkara belum dilakukan. Hal tersebut juga diperburuk dengan tidak dikenalnya konsep insolvency test sebagai syarat dalam pengajuan permohonan PKPU dalam Undang-Undang Kepailitan di Indonesia.

Oleh karena itu, hakim dituntut untuk menggunakan kebijaksanaannya dalam memeriksa perkara kepailitan yang belum memuat pengaturan sempurna. Apabila ditinjau dari segi normatif, Hakim pada dasarnya memiliki kewenangan yang bersifat pasif dan terikat pada apa yang dikemukan dalam Permohonan para pihak (secundum allegata iudicare). ${ }^{1}$ Undang-Undang Kepailitan seakan-akan memaksa Hakim untuk memutus perkara kepailitan hanya dengan berpatokan pada syarat yang ditentukan dalam Undang-Undang Kepailitan, sehingga membatasi ruang gerak bagi Hakim untuk memutus secara objektif.

Namun pada kasus kepailitan PT Dirgantara Indonesia, Majelis Hakim tingkat Kasasi melalui Putusan Mahkamah Agung Nomor 075 K/Pdt.Sus/2007 membatalkan status kepailitan dari PT Dirgantara Indonesia yang sebelumnya telah dinyatakan pailit melalui putusan Pengadilan Niaga pada Pengadilan Jakarta Pusat pada Putusan Nomor 41/Pailit/2007/PN Niaga Jkt. Pst. Majelis Hakim tingkat kasasi berpandangan bahwa kemampuan usaha yang dimiliki oleh PT Dirgantara Indonesia dinilai masih mampu untuk kembali menjalankan perusahaan sehingga PT Dirgantara masih memiliki peluang yang besar untuk dapat menghasilkan pemasukan bagi perusahaan. Oleh karena itu, penjatuhan pailit terhadap PT Dirgantara Indonesia dinilai tidaklah tepat dan Debitor haruslah diberikan kesempatan untuk melakukan restrukturisasi dengan

${ }^{1}$ Elisabeth Nurhaini Butar, 'Kebebasan Hakim Perdata dalam Penemuan Hukum dan Anatomi dalam Penerapannya’ (2011) 21 Jurnal Mimbar Hukum.[70]. 
berkoordinasi dengan para Kreditor sebagai upaya untuk membayarkan kewajiban-kewajibannya.

Penolakan terhadap status kepailitan yang didasarkan pada keadaan solven Debitor tersebut tidak hanya dialami oleh PT Dirgantara Indonesia. Putusan Mahkamah Agung pada tingkat Kasasi Nomor 704 K/Pdt.Sus/2012 telah membatalkan Putusan Pengadilan Niaga pada Pengadilan Negeri Jakarta Pusat Nomor 48/Pailit/2012/PN.Niaga.Jkt.Pst yang sebelumnya telah menyatakan PT Telekomunikasi Seluler (selanjutnya disebut PT Telkomsel) berada dalam keadaan pailit. Mahakamah Agung dalam Putusan tersebut berpandangan bahwa PT Telkomsel pada dasarnya masih memiliki aset dengan jumlah yang lebih besar apabila dibandingkan dengan kewajiban yang harus dibayarkannya. Lebih lanjut, Mahkamah Agung turut berpendapat bahwa meskipun Undang-Undang Kepailitan tidak mensyaratkan mengenai nominal dari utang, namun Majelis Hakim Pengadilan Niaga seharusnya menyertakan adanya pertimbangan yang dilandaskan oleh logika perpikir dan ketelitian dalam memutus perkara, terutama dalam hal pengabulan Permohonan Pailit. ${ }^{2}$

Hal serupa juga terjadi pada ranah Permohonan PKPU, dimana Permohonan PKPU yang diajukan oleh mantan pilot Lion Air, yaitu Amsal Salomo Tampubolon (Pemohon PKPU I) dan Erlang Airlangga (Pemohon PKPU II) terhadap PT Lion Mentari Airlines (Termohon PKPU II) atas piutang sebesar Rp780.000.000,- (tujuh ratus delapan puluh juta rupiah) sebagai akibat dari Termohon PKPU tidak melaksanakan Penetapan Eksekusi dan Aanmaning Pengadilan Negeri Jakarta Pusat pada Putusan Nomor 01/2019/EKS. jo. Putusan Nomor 51/Pdt.Sus-PHI/2017/ PN Jkt. Pst. jo. Nomor 260 K/Pdt.Sus-PHI/2018 tertanggal 15 Januari 2019. Majelis Hakim Pengadilan Niaga pada Pengadilan Negeri Jakarta Pusat melalui Putusan Nomor 196/Pdt.Sus-PKPU/2019/PN Niaga Jkt. Pst., tertanggal 2 Oktober 2019 menolak Permohonan PKPU yang diajukan oleh Para Pemohon PKPU tersebut

2 Syah Yannuar Ariefandi, 'Pembatalan Putusan Pailit Akibat Adanya Utang Yang Tidak Dapat Dibuktikan Secara Sederhana Dalam Perjanjian Kerjasama (Kajian Putusan Mahkamah Agung No. 704.K/Pdt.Sus/2012)' (2013) Artikel Ilmiah Hasil Peneitian Mahasiswa.[8]. 
yang didasarkan pada pertimbangan bahwa Para Pemohon PKPU tidak berhasil membuktikan secara sederhana dalil Permohonannya yang menyatakan bahwa PT Lion Mentari Airlines telah tidak dapat melanjutkan pembayarannya karena Majelis Hakim berpendapat bahwa PT Lion Mentari Airlines adalah Perusahaan yang masih sehat dan mampu melaksanakan pembayaran tersebut.

Sikap Majelis Hakim pada kedua kasus tersebut yang menyertakan pertimbangan keadaan solven dari Debitor dalam menjatuhkan Putusan cenderung ditafsirkan sebagai tindakan yang dilakukan diluar yang diamanatkan Undang-Undang, mengingat pertimbangan keadaan keuangan Debitor bahkan tidak diatur dalam Undang-Undang Kepailitan. Permasalahan-permasalahan yang telah disampaikan Penulis di atas menunjukkan bahwa ketentuan mengenai insolvensi dalam Undang-Undang Kepailitan sering menimbulkan pertentangan dengan norma yang hidup dan berkembang ditengah masyarakat dan mengancam eksistensi dari Debitor, sehingga medesak Hakim untuk mengambil sikap dengan mengambil langkah untuk melakukan penafsiran konsep insolvensi yang berbeda dengan yang ada dalam Undang-Undang Kepailitan. Hal tersebut yang kemudian menjadi alasan Penulis untuk melakukan penulisan hukum dengan judul Keabsahan Keadaan Solven Debitor sebagai Dasar Pertimbangan dalam Perkara Kepailitan.

\section{Metode Penelitian}

Penelitian ini menggunakan metode penelitian yuridis normatif yang disertai dengan dominasi penggunaan data-data sekunder yang berupa bahan hukum primer, bahan hukum sekunder dan bahan hukum tersier. Metode pendekatan yuridis normatif yang dilandasi dengan pencarian data sebanyak mungkin dan memberi fokus pada peraturan-peraturan yang berlaku serta literatur-literatur yang memiliki keterkaitan dengan permasalahan yang berkaitan dengan penulisan skripsi ini seperti jurnal nasional maupun internasional. ${ }^{3}$ 2006).[13].

${ }^{3}$ Soerjono Soekanto dan Sri Mamudji, Penelitian Hukum Normatif (Raja Grafindo Persada 


\section{Ketentuan Umum mengenai Insolvensi}

Penggunaan istilah Insolvensi dan kepailitan pada praktiknya cenderung diartikan sebagai suatu hal yang sama. Apabila ditinjau dari segi teoritis, kedua hal tersebut pada dasarnya merupakan hal yang sangat berbeda. Insolvensi (insolvency) merupakan suatu keadaan keuangan (a financial state) suatu subjek hukum perdata (legal entity), sedangkan kepailitan (bankruptcy) adalah keadaan hukum (legal state) dari suatu subjek hukum perdata (legal entity). Debitor hanya dapat dikatakan bangkrut (pailit) oleh pengadilan apabila Debitor telah berada dalam keadaan insolven dan bukan sebaliknya, yaitu Debitor yang telah insolven tidak demi hukum menjadi bangkrut (pailit) tetapi harus terlebih dahulu dimohonkan kepailitannya kepada pengadilan. ${ }^{4}$

Lebih lanjut, Debitor dinyatakan berada dalam keadaan insolven apabila Debitor tersebut tidak mampu secara finansial membayar sebagian besar utangutangnya atau nilai aktiva atau asetnya kurang dari pasiva atau liabilities-nya. Pailit sendiri dianggap sebagai kegagalan yang diartikan dalam beberapa arti, yaitu kegagalan ekonomi (economic failure) dan kegagalan keuangan (financial failure). Kegagalan dalam arti ekonomi biasanya berarti bahwa perusahaan ini berarti tingkat labanya sendiri lebih kecil dari kewajiban sehingga terjadilah kegagalan akibat arus kas sebenarnya dari perusahaan tersebut jauh di bawah arus kas yang diharapkan. Disisi lain, kegagalan keuangan bisa diartikan sebagai keadaan insolvensi, yaitu dalam ukuran sebagai kekayaan bersih negatif dalam neraca konvensional atau nilai sekarang dari arus kas yang diharapkan lebih kecil dari kewajiban. ${ }^{5}$

Sejatinya, istilah insolvensi telah tercantum dalam ketentuan yang ada di Undang-Undang Kepailitan, namun ketentuan tersebut tidak merumuskan secara rinci mengenai pengertian dari insolvensi itu sendiri. Hal tersebut dapat dilihat pada penjabaran dalam Pasal 2 ayat (1) Undang-Undang Kepailitan, yang berbunyi:

${ }^{4}$ Sutan Remy Sjahdeini, Sejarah, Asas, dan Teori Hukum Kepailitan Memahami UndangUndang No. 37 Tahun 2004 tentang Kepailitan dan Penundaan Kewajiban Pembayaran (Prenadamedia Grup 2016). [3].

${ }^{5}$ Adnan, Muhammad Akhyar dan Eha Kurniasih, 'Analisis Tingkat Kesehatan Perusahaan Untuk memprediksi Potensi Kebangkrutan dengan Pendekatan Altman (Kasus Pada Sepuluh Perusahaan di Indonesia)', (2000) 4 Jurnal Akuntansi \& Auditing Indonesia.[137]. 
“Debitur yang mempunyai dua atau lebih kreditur dan tidak membayar lunas sedikitnya satu utang yang telah jatuh waktu dan dapat ditagih, dinyatakan pailit dengan Putusan Pengadilan, baik atas permohonan sendiri maupun atas permohonan satu atau lebih krediturnya".

Konsep insolvensi dalam hal ini diartikan sebagai "tidak membayar lunas" utang-utangnya. Dengan kata lain, Debitor dianggap sudah pernah membayar namun suatu saat berhenti. ${ }^{6}$

\section{Parameter Debitor dinyatakan Solven}

Parameter keadaan solven Debitor pada umumnya dapat diketahui melalui mekanisme insolvency test. Insolvency test merupakan uji kemampuan Debitor dalam rangka pembayaran utang-utangnya yang mencakup uji arus kas perusahaan dan uji neraca perusahaan. ${ }^{7}$

Hukum kepailitan di Amerika Serikat sering menjadi acuan dalam pembentukan Undang-Undang. Hal ini dikarenakan negara berbasis common law ini dinilai memiliki perkembangan hukum kepailitan yang sangat pesat. Hukum kepailitan di Amerika Serikat dituangkan dalam Bankrupty Reform Act of 1978 atau Bankruptcy Code. Undang-Undang tersebut tentunya telah memiliki pengaturan mengenai Insolvency Test, dimana Insolvency Test merupakan hal yang penting di Amerika Serikat guna menentukan apakah suatu perusahaan berbadan hukum atau debitor dianggap solven atau tidak. Selain itu, Uniform Fradulent Transfer Act (UFTA) juga hadir sebagai pemberi solusi mengenai adanya insolvency test yang dapat diterapkan dalam hal membuktikan debitor yang telah insolven untuk dimohonkan dan diputuskan pailit. ${ }^{8}$

Meskipun begitu, beberapa negara telah menerapkan mekanisme Insolvency test dan juga menjadikannya sebagai syarat yang dianggap penting dalam perkara kepailitan. Hakim pada negara-negara yang menganut Common Law System

${ }^{6}$ Man S. Sastrawidjadja, Hukum Kepailitan dan Penundaan Kewajiban Pembayaran Utang (PT Alumni 2005).[18].

${ }^{7}$ Gedalya Iryawan Kale, 'Syarat Kepailitan Sebagai Bentuk Perlindungan Hukum Debitor Dalam Undang-Undang Nomor 37 Tahun 2004', (2018) 6 Jurnal Kertha Semaya.[7].

${ }^{8}$ Luh Ayu Maheswari Prabaningsih, 'Pengaturan Insolvency Test Dalam Penjatuhan Putusan Pailit Terhadap Perusahaan’ (2019) 7 Jurnal Kertha Semaya.[6-7]. 
memiliki kriteria tersendiri dalam menggunakan insolvency test, yaitu: ${ }^{9}$

1. The Abiliti to Pay Solvency Test (Cash Flow Solvency Test)

Pendekatan cash flow solvency test merupakan jenis pendekatan yang digunakan untuk menilai kemampuan bayar Debitor untuk menentukan apakah suatu debitor dapat membayar utangnya ketika utangnya telah jatuh tempo, sehingga Debitor yang berhenti membayar utang dikarenakan ketiadaan uang tunai (cash) dinilai telah insolven.

2. The Balance Sheet Test

Pendekatan the balance sheet test merupakan bentuk penilaian utang berdasarkan perbandingan antara aset yang dimiliki debitur dengan besarnya kewajiban yang harus dipenuhi debitur, sehingga Debitor dianggap insolven apabila seluruh kewajiban untuk membayar (termasuk membayar biaya likuidasi) lebih besar jumlahnya dari aset yang dimiliki oleh Debitor.

3. The Capital Adequacy Test/Analisis Transaksional

Pendekatan the capital adequacy test atau yang biasa disebut dengan pendekatan going concern value merupakan bentuk penilaian utang test penilaian utang yang secara tidak langsung dianut oleh UndangUndang Kepailitan dan praktik bisnis. Hal ini diwujudkan melalui adanya pelaksanaan PKPU dengan tujuan untuk memberikan kesempatan kepada Debitor untuk mengelola perusahaan dari awal, sehingga Debitor dapat melakukan restrukturisasi utang. ${ }^{10}$

Lebih lanjut, sistem kepailitan di negara-negara Common Law juga turut mensyaratkan adanya minimal jumlah minimal utang Debitor dalam pengajuan permohonan perkara Kepailitan, seperti halnya pada sistem kepailitan di negara Common Law, seperti sistem Kepailitan di Hongkong yang menerapkan adanya penentuan jumlah minimum utang sebagai syarat pengajuan permohonan kepailitan, yaitu minimum HK\$5.000,-. ${ }^{11}$ Dengan kata lain, sistem kepailitan di

\footnotetext{
${ }^{9}$ Elyta Ras Ginting, Hukum Kepailitan: Teori Kepailitan (Sinar Grafika 2018).[117-120].

${ }^{10}$ Catur Irianto, 'Penerapan Asas Kelangsungan Usaha dalam Penyelesaian Perkara Kepailitan dan Penundaan Kewajiban Penundaan Utang (PKPU)’ (2015) 4 Jurnal Hukum dan Peradilan. [404].

${ }^{11}$ Hadi Shubhan, Hukum Kepailitan Prinsip, Norma dan Praktek di Pengadilan (Kencana 2008). [37].
} 
Hongkong ditujukan hanya terhadap Debitor yang sudah berada dalam keadaan "sekarat" dan tidak memiliki sanggup lagi untuk membayarkan kewajibankewajibannya yang diakibatkan adanya krisis finansial yang mengakibatkan jumlah aset yang dimiliki jauh lebih sedikit dibandingkan jumlah utang-utangnya.

Apabila dilakukan perbandingan, Undang-Undang Kepailitan di Indonesia sejatinya tidak memberi pengaturan yang menyatakan bahwa Insolvency Test sebagai syarat dalam pengajuan permohonan perkara Kepailitan. Undang-Undang Kepailitan cukup mensyaratkan hakim untuk melakukan pembuktian sederhana terhadap permohonan terlebih dahulu dan secara normatif tidak bertentangan dengan persyaratan dalam Undang-Undang. ${ }^{12}$

Sistem Kepailitan di Indonesia tentunya menganut konsep yang berbeda. Debitor dapat dinyatakan dalam keadaan insolvensi apabila telah memenuhi 2 keadaan, antara lain:

1. Setelah dinyatakan Pailit oleh Putusan Pengadilan

Debitor Pailit selanjutnya akan segera memasuki tahapan pengurusan pada Rapat Kreditor. Dalam rapat Kreditor tersebut, Debitor akan diberikan kesempatan untuk menawarkan Proposal Rencana Perdamaian dalam waktu paling lambat 8 hari sebelum Rapat Verifikasi (Pencocokan Piutang) dimulai. Apabila dalam rentang waktu tersebut Debitor tidak mengajukan Proposal Rencana Perdamaian atau Debitor telah mengajukan Proposal Rencana Perdamaian namun tidak tercapainya kesepakatan berdasarkan ketentuan jumlah suara yang ada pada Pasal 151 Undang-Undang Kepailitan, maka akan menyebabkan Debitor dinyatakan berada dalam keadaan insolvensi sebagaimana yang telah diamanatkan Pasal 178 ayat (1) Undang-Undang Kepailitan.

\section{Melalui PKPU}

Apabila ditinjau dari segi waktu pemeriksaan, proses PKPU pada dasarnya dapat ditempuh melalui 2 tahapan, yaitu PKPU Sementara dan PKPU Tetap.

${ }^{12}$ Gedalya Iryawan Kale, Op.Cit.[7]. 
PKPU sementara merupakan proses pertama dalam penyelesaian permohonan PKPU. Pasal 224 Ayat (2) Undang-Undang Kepailitan menerangkan bahwa pengadilan niaga harus mengabulkan permohonan PKPU dengan memberi jangka waktu maksimum 45 hari terhitung sejak putusan PKPU diucapkan untuk memberikan kesempatan kepada debitor dalam mempresentasikan rencana perdamaian yang diajukannya sebelum diselenggarakannya rapat Kreditor.

Setelah pemberian jangka waktu 45 hari melalui PKPU Sementara berakhir, Debitor pada dasarnya diberikan kesempatan kembali untuk memohonkan perpanjangan masa PKPU dengan mengajukan permohonan PKPU Tetap guna mendapatkan perpanjangan jangka waktu maksimum 270 hari dalam menyusun Proposal Rencana Perdamaian. Apabila dalam rentang waktu tersebut, rencana perdamaian tidak diterima oleh para Kreditor, atau perdamaian tersebut tidak disahkan oleh Pengadilan Niaga, atau tidak tercapainya kesepakatan apapun, maka Debitor akan segera dinyatakan berada dalam keadaan Pailit dan langsung masuk ke dalam fase insolvensi.

\section{Kendala Penerapan Insolvency Test di Indonesia}

Insolvency test sendiri pernah diterapkan dalam sistem Kepailitan Indonesia, tepatnya pada Pasal 1 Failissementsverordening atau Undang-Undang tentang Kepailitan sebagaimana termuat dalam Staatsblad Tahun 1905 Nomor 217 jo. Staatsblad Tahun 1906 Nomor 348 (selanjutnya disebut Failissementsverordening), yang menyatakan bahwa persyaratan pailit adalah setiap berutang dalam keadaan berhenti membayar utang-utangnya, berdasarkan putusan Hakim, baik atas pelaporan sendiri, baik atas permintaan seorang atau lebih para berpiutangnya (kreditornya). Ketentuan ini kemudian mendapatan perubahan pada Pasal 1 PERPU No. 1 Tahun 1998 jo Undang-Undang No. 4 Tahun 1998 yang mensyaratkan Debitor harus mempunyai dua atau lebih kreditor dan tidak membayar sedikitnya satu utang yang telah jatuh waktu dan dapat ditagih. dinyatakan pailit dengan putusan Pengadilan yang berwenang, baik atas permohonannya sendiri (si 
Debitor), maupun atas permintaan seorang atau lebih Kreditornya. Konsep ini juga turut diadopsi dalam Pasal 2 ayat (1) Undang-Undang Kepailitan.

Adanya perubahan yang meniadakan konsep insolvency test dan lebih menekankan pada keadaan berhenti yang didasarkan pada iktikad Debitor untuk membayar pada sistem Kepailitan di Indonesia turut mengundang kontroversi dari beberapa pihak. Ketiadaan insolvency test ini dinilai akan menimbulkan kerugian bagi pihak Debitor. Sutan Remy Syahdeni berpendapat bahwa keadaan berhenti membayar seharusnya ditinjau berdasarkan keadaan keuangan Debitor yang dinilai berdasarkan financial audit atau financial due diligence oleh seorang akuntan publik independen, sehingga menghasilkan penilaian yang lebih objektif apabila hanya mendasarkan pada sikap Debitor yang tidak mau membayar utangutangnya semata. ${ }^{13}$

Lebih lanjut, Hikmahanto Juwana kembali menegaskan bahwa UndangUndang Kepailitan sejatinya memiliki tujuan untuk membebaskan Debitor yang sudah tidak mampu lagi membayar utangnya disamping memfasilitasi Kreditor untuk mengambil haknya kembali dari Debitor. Lazimnya keadaan berhenti membayar tersebut bukan disebabkan karena hal-hal yang sepele melainkan sebab yang substansial sehingga aktivitas bisnisnya menjadi sangat sulit untuk dilaksanakan. ${ }^{14}$ Ketiadaan insolvency test sebagai persyaratan kumulatif dalam Undang-Undang Kepailitan dianggap tidak menjadi cara yang solutif yang cenderung digunakan hanya sebagai alat penagihan utang Debitor secara paksa guna melindungi kepentingan Kreditor semata dan tanpa memperhatikan perlindungan seimbang terhadap Debitor.

Namun bagi sebagian pihak, ketiadaan konsep insolvency test dalam sistem Kepailitan di Indonesia ini dianggap sebagai suatu langkah yang sudah tepat. Ricardo Simanjuntak berpendapat bahwa Debitor pada dasarnya tidak dapat menghindar dengan alasan apapun untuk tidak membayarkan utangnya yang telah jatuh waktu, kecuali apabila Debitor itu semata-mata hendak "gemplang".

\footnotetext{
${ }^{13}$ Sutan Remy Sjahdeini, Op.Cit.[3].

${ }^{14}$ Sunarmi, Prinsip Keseimbangan Dalam Hukum Kepailitan di Indonesia (PT Softmedia 2010).[318].
} 
Dengan demikian, Undang-Undang Kepailitan dalam hal ini berperan untuk menjangkau Debitor-Debitor yang bermental tidak mau melunasi utang. Lebih lanjut, beliau juga menguraikan bahwa istilah bankrupt haruslah dibedakan dengan insolven karena meskipun Debitor dapat dinyatakan bankrupt apabila telah memenuhi Pasal 1 ayat (1) Undang-Undang Kepailitan, namun Debitor pada dasarnya hanya berada dalam keadaan insolvensi yang dipreasumsikan. Artinya, apabila rencana perdamaian Debitor disetujui Kreditor, maka Debitor sejatinya dapat membuktikan bahwa dirinya masih mampu dan mau melunasi tagihannya. Hal itu tentunya berbeda apabila rencana perdamaian Debitor ditolak para kreditornya, barulah Debitor dapat dinyatakan insolven. ${ }^{15}$

Hambatan lain dalam penerapan insolvency test di Indonesia adalah karena konsep insolvensi pada dasarnya berkaitan tentang pembukuan yang ada dalam Pasal 47 KUHD yang pada intinya menyatakan bahwa keadaan solven seseorang dapat ditentukan apabila telah mengalami kerugian secara terus-menerus hingga menggerus modal yang dimiliknya sebanyak lebih dari $50 \%$. Hal itu tentunya hanya dapat dinilai berdasarkan Laporan Keuangan dari Debitor. Lebih lanjut, sistem pembuktian yang dianut pada hukum acara perdata Indonesia didasarkan pada pasal 1865 HIR yang menganut prinsip "siapa yang mendalilkan, dia yang membuktikan". Oleh karena itu, Kreditor dituntut untuk dapat memperoleh bukti Laporan Keuangan dari Debitor sebagai bahan untuk melakukan insolvency test.

Hal ini tentunya akan semakin memberatkan Kreditor mengingat tidakjarang ditemukan adanya praktik penyelewengan atas laporan keuangan perusahaan (Financial Statement Fraud), yang disengaja oleh manajemen perusahaan dalam bentuk salah saji material Laporan Keuangan yang merugikan investor maupun Kreditor. ${ }^{16}$ Terlebih lagi, Kreditor tentunya akan mendapatkan kesulitan dalam mengakses Laporan Keuangan dari Perusahaan Tertutup. ${ }^{17}$ Kesulitan-kesulitan

\footnotetext{
15 Ricardo Simanjuntak, 'Relevansi Eksekusi Putusan Pengadilan Niaga dalam Transaksi Bisnis Internasional' (2003) 22 Jurnal Hukum Bisnis.[8-5].

${ }^{16}$ Amrizal, 'Pencegahan dan Pendeteksian Kecurangan Oleh Internal Auditor' http://bpkp. go.id/public/upload/unit/investigasi/files/Gambar/PDF/cegah_deteksi.pdf, diakses pada 19 Januari 2021.

${ }^{17}$ Ricardo Simanjuntak, Op. Cit.[8-15].
} 
tersebut sejatinya merupakan alasan ditiadakannya insolvency test yang dahulu diterapkan pada Failissementsverordening. Proses pembuktian keadaan berhenti Debitor yang memerlukan proses pembuktian secara mutlak pada saat itu banyak menimbulkan kesulitan. ${ }^{18}$

Faktanya, Singapura yang berbasis pada sistem common law sudah melakukan amandemen terhadap Section 227B(1)(b) Singapore Company Act pada tahun 2017, yang sebelum amandemen mensyaratkan sistem kepailitan ditujukan hanya terhadap kriteria perusahaan yang "is or will be unable to pay its debts" atau dengan kata lain telah dianggap insolven. Hal ini menyebabkan proses restrukturisasi dalam sistem kepailitan tidak berjalan efektif untuk merehabilitasi keadaan perusahaan sudah terlanjur insolven. Oleh karena itu, amandemen dilakukan untuk menurunkan standar persyaratan dengan mengubahnya menjadi "is likely to become unable to pay" yang dituangkan dalam Section 89 (1) pada Singapore Insolvency, Restructuring and Dissolution Act 2018. Ini berarti bahwa proses restrukturisasi pada sistem kepailitan juga dapat ditujukan perusahaan yang mengalami kesulitan keuangan dan dipreasumsikan tidak akan dapat membayarkan kewajibannya. ${ }^{19}$

Sistem baru yang diterapkan oleh Singapura memiliki persamaan dengan sistem kepailitan yang dianut oleh Indonesia yang berbasis civil law karena Singapura sendiri pada dasarnya telah menyadari adanya kesulitan dalam penerapan insolvency test dalam sistem kepailitan mereka. Kesulitan serupa tentunya akan juga terjadi dan menjadi masalah baru apabila insolvency test turut diterapkan dalam sistem kepailitan di Indonesia.

\section{Kedudukan Keadaan Solven Debitor Dalam Pertimbangan Hakim}

Terlepas dari adanya kontroversi pemberlakuan insolvency test pada sistem kepailitan di Indonesia, prosedur dan syarat-syarat pengajuan perkara

${ }^{18}$ Aria Suyudi, Kepailitan di Negara Pailit (Pusat Studi Hukum \& Kebijakan Indonesia 2004). [119-120].

${ }^{19}$ Hadi Shubhan, Op. Cit.[37]. 
Kepailitan di Indonesia secara tegas tidak mensyaratkan terlebih dahulu nilai nominal utang/piutang dan juga tidak mempersyaratkan terlebih dahulu perusahaan atau perseorangan untuk insolvens. ${ }^{20}$ Namun Majelis Hakim pada kasus PT Dirgantara Indonesia dan PT Lion Mentari Airlines sejatinya telah melakukan interpretasi terhadap perhitungan mampu atau tidaknya Debitor dalam Undang-Undang Kepailitan.

Majelis hakim dalam perkara tersebut tidak lagi berpikir secara legistis, melainkan telah mengubah pola berpikir dengan melandaskan pada metode interpretasi teleologis, yakni apabila makna Undang-Undang ini diterapkan berdasarkan tujuan kemasyarakatan. ${ }^{21}$ Perubahan pola pikir ini turut mengubah tujuan dari putusan hakim Pengadilan Niaga yang semula bertujuan untuk melindungi kepentingan Kreditor saja, menjadi bertujuan untuk kepentingan Debitor, para stakeholder, serta kepentingan seluruh masyarakat, sebagimana konsep dalam teori utility yang dikemukakan John Stuart Mill. ${ }^{22}$ Dengan demikian, interpretasi hakim tersebut telah merubah fungsi dari UndangUndang Kepailitan yang sebelumnya berkedudukan sebagai alat untuk mengancam Debitor yang tidak mau (unwilling) bukan tidak mampu (unable) melaksanakan kewajibannya. Ketidakmauan hanya karena adanya masalah perdata diantara mereka. ${ }^{23}$

Lebih lanjut, Pasal 5 ayat (1) Undang-Undang Nomor 49 tahun 2009 tentang Kekuasaan Kehakiman (selanjutnya disebut Undang-Undang Kekuasaan Kehakiman) juga memberikan wewenang kepada Hakim untuk menciptakan norma hukum melalui penemuan hukum dengan menggali nilainilai dalam masyarakat. Hal ini selaras dengan pendapat Satjipto Rahardjo yang menegaskan bahwa Hakim bukan merupakan les bouches, qui prononcent les paroles de la loi (mulut yang mengucapkan kata-kata Undang-Undang),

\footnotetext{
${ }^{20}$ ibid.

${ }^{21}$ Sudikno Mertokusumo, Penemuan Hukum (Citra Aditya Bakti 1993).[15].

${ }^{22}$ Ricardo Simanjuntak, 'Rancangan Perubahan Undang-undang Kepailitan dalam Pengacara (Komentar Terhadap Perubahan Undang-undang Kepailitan)' (2002) 17 Jurnal Hukum Bisnis.

${ }^{23}$ Hikmahanto Juwana, 'Solusi Pascapemailitan PT DI', http:/ / www.kompas.com/kompascetak/0709/18/opini/3836688.htm, diakses pada 02 Februari 2021.
} 
melainkan hakim merupakan vigilante (seorang yang menegakkan hukum dengan caranya sendiri). ${ }^{24}$

Adapun intepretasi Hakim dalam kedua perkara tersebut dilandaskan pada penerapan asas keberlangsungan usaha. Asas kelangsungan usaha ini membuka kesempatan bagi debitor untuk melakukan restrukturisasi terhadap perusahaannya sebagai bentuk pencegahan atas adanya indikasi kesewenang-wenangan pihak kreditor yang selalu berupaya untuk mendapatkan pembayaran atas masingmasing tagihannya terhadap debitor. ${ }^{25}$ Namun penerapan asas keberlangsungan usaha ini dinilai kurang tepat karena seperti yang telah disebutkan dalam uraian sebelumnya, asas keberlangsungan usaha dalam perkara kepailitan hanya diterapkan apabila telah memasuki mekanisme kepailitan.

Sejatinya, pemecahan masalah dalam kedua perkara tersebut adanya diperlukannya perlindungan seimbang antara Kreditor dan Debitor maupun terhadap masyarakat bisnis. Meskipun Undang-Undang Kepailitan dan Putusan Pengadilan pada dasarnya bertujuan untuk memberikan perlindungan bagi para pihak-pihak yang berperkara, namun perlindungan yang diberikan juga tidak boleh sampai merugikan kepentingan masyarakat lain. ${ }^{26}$ Keberadaan hukum sejatinya harus memberikan perlindungan yang seimbang juga terhadap para anggota masyarakat yang melakukan hubungan hukum, sehingga pelaksanaan Undang-Undang melalui pengadilan yang berperan sebagai lembaga penerapan hukum juga dapat menghasilkan putusan-putusan yang efektif. ${ }^{27}$

Hal ini juga sejalan dengan penerapan asas keseimbangan yang diadopsi secara tegas dalam Undang-Undang Kepailitan yang memberikan perlindungan seimbang, mengutamakan keadilan dan melindungi kepentingan para pihak,

\footnotetext{
${ }^{24}$ Satjipto Rahardjo, Lapisan-lapisan dalam Studi Hukum (Bayumedia Publishing 2009).[55].

${ }^{25}$ Victorianus Randa Puang, Penerapan Asas Pembuktian Sederhana dalam Penjatuhan Putusan Pailit (PT Sarana Tutorial Nurani Sejahtera 2011).[10].

${ }^{26}$ Marc Lampe, 'Mediation as An Ethical Adjunc of Stakeholder Theory' (2001) Journal of Bussines Ethics.[165-173].

${ }^{27}$ Krista Yitawati, 'Analisis Asas Pemberian Manfaat dan Perlindungan yang Seimbang Antara Kreditor dan Debitor pada Pasal 2 Undang-Undang Nomor 37 Tahun 2004 Tentang Kepailitan Dan PKPU Mengenai Syarat-Syarat Pailit (Kajian Putusan Pailit PT Dirgantara Indonesia Dan PT Televisi Pendidikan Indonesia)' Tesis, (Universitas Sebelas Maret).[30].
} 
meliputi segala hal esensial yang dibutuhkan guna menciptakan sarana penyelesaian sengketa utang-piutang secara cepat, adil, terbuka, dan efektif. ${ }^{28}$ Konsep asas keseimbangan ini dapat dijadikan sebagai landasan filosofis perlindungan hukum Debitor sehubungan dengan tidak adanya insolvency test dalam penyelesaian sengketa kepailitan.

Lebih lanjut, hal ini tentunya juga memiliki keterkaitan dengan nilai keadilan dan nilai kepastian hukum bagi debitor. ${ }^{29}$ Apabila suatu Undang-Undang diterapkan hanya secara tekstual semata, maka hal tersebut tidak dapat terwujudnya keadilan, karena hanya melindungi kepentingan satu pihak saja secara individual dan mengabaikan pihak lain dan kepentingan masyarakat. ${ }^{30}$ Pasal 1 ayat (3) UUD 1945 menjamin adanya perlindungan hukum yang diberikan oleh negara dengan menyatakan bahwa "Indonesia adalah negara hukum". Jaminan perlindungan hukum tersebut diwujudkan melalui upaya menciptakan peraturan hukum dengan pemberlakuan asas keseimbangan dalam Undang-Undang Kepailitan sebagai landasan filosofis perlindungan hukum Debitor solven dalam perkara kepaillitan.

\section{Kesimpulan}

Secara umum, Debitor dinyatakan berada dalam keadaan insolven apabila Debitor tersebut tidak lagi memiliki kemampuan secara finansial untuk melakukan pelunasan terhadap utang-utangnya, serta dapat pula ditentukan dari nilai aktiva atau asetnya yang jumlahnya kurang dari nilai passiva atau liabilitiesnya. Penerapan insolvency test di negara-negara common law biasanya digunakan dengan menggunakan 3 cara, antara lain The Abiliti to Pay Solvency Test (Cash Flow Solvency Test), The Balance Sheet Test, The Capital Adequacy Test/Analisis Transaksional. Namun Undang-Undang Kepailitan sendiri menganut prinsip yang berbeda, dimana insolvensi diartikan sebagai "tidak membayar lunas" utang-utangnya. Dengan kata lain, Debitor dianggap sudah pernah melakukan

${ }^{28}$ Adrian Sutedi, Hukum Kepailitan (Ghalia Indonesia 2009).[30].

${ }^{29}$ R. D. Widijowati, Hukum Dagang (ANDI 2012).[226]. Bisnis.[42].

${ }^{30}$ Sjahdeini, Sutan Remy. 'Sejarah Hukum Kepailitan di Indonesia' (2001) 12 Jurnal Hukum 
pembayaran terhadap utang-utangnya namun suatu saat berhenti membayar. Lebih lanjut, Debitor dapat dinyatakan dalam keadaan insolvensi apabila Debitor idak mengajukan Proposal Rencana Perdamaian atau Debitor telah mengajukan Proposal Rencana Perdamaian namun tidak tercapainya kesepakatan dengan Kreditor pada tahap pembahasan Rencana Perdamaian.

Undang-Undang Kepailitan pada dasarnya memiliki tujuan sebagai jalur penyelesaian sengketa utang piutang yang berkeadilan, baik kepada Kreditor maupun Debitor. Namun permasalahan yang timbul akibat tidak diterapkannya mekanisme insolvency test sebagai syarat dalam perkara kepailitan menimbulkan perdebatan di berbagai kalangan yang kemudian meragukan pemberlakuan dari Undang-Undang Kepailitan itu sendiri. Atas permasalahan tersebut, Hakim sebagai tonggak pelaksana Undang-Undang dituntut untuk menengahi permasalahan yang terjadi dengan menerapkan interpretasi hukum yang didasarkan pada asas hukum sebagai landasan filosofis guna menciptakan keseimbangan bagi para pihak maupun masyarakat bisnis.

\section{Daftar Bacaan}

\section{Buku}

Adrian Sutedi, Hukum Kepailitan (Ghalia Indonesia 2009).

Aria Suyudi, Kepailitan di Negara Pailit (PusatStudi Hukum \& Kebijakan Indonesia 2004). Elyta Ras Ginting, Hukum Kepailitan: Teori Kepailitan (Sinar Grafika 2018).

Hadi Shubhan, Hukum Kepailitan Prinsip, Norma dan Praktek di Pengadilan (Kencana 2008).

Man S. Sastrawidjadja, Hukum Kepailitan dan Penundaan Kewajiban Pembayaran Utang (PT Alumni 2006).

R. D. Widijowati, Hukum Dagang (ANDI 2012).

Satjipto Rahardjo, Lapisan-lapisan dalam Studi Hukum (Bayumedia Publishing 2009).

Soerjono Soekanto dan Sri Mamudji, Penelitian Hukum Normatif (PT Raja Grafindo Persada 2003). 
Clarita Stefanie, dkk: Keabsahan Keadaan Solven...

Sudikno Mertokusumo, Penemuan Hukum (Citra Aditya Bakti: 1993).

Sunarmi, Prinsip Keseimbangan Dalam Hukum Kepailitan di Indonesia (PT Softmedia 2010).

Sutan Remi Sjahdeini, Sejarah, Asas, dan Teori Hukum Kepailitan Memahami UndangUndang No. 37 Tahun 2004 tentang Kepailitan dan Penundaan Kewajiban Pembayaran (Prenadamedia Group 2016).

Victorianus Randa Puang, Penerapan Asas Pembuktian Sederhana dalam Penjatuhan Putusan Pailit (PT Sarana Tutorial Nurani Sejahtera 2011).

\section{Jurnal}

Adnan, Muhammad Akhyar dan Eha Kurniasih, 'Analisis Tingkat Kesehatan Perusahaan Untuk memprediksi Potensi Kebangkrutan dengan Pendekatan Altman (Kasus Pada Sepuluh Perusahaan di Indonesia)' (2000) 4 Jurnal Akuntansi \& Auditing Indonesia.[137].

Catur Irianto, 'Penerapan Asas Kelangsungan Usaha dalam Penyelesaian Perkara Kepailitan dan Penundaan Kewajiban Penundaan Utang (PKPU)’ (2015) 4 Jurnal Hukum dan Peradilan.

Elisabeth Nurhaini Butar, 'Kebebasan Hakim Perdata dalam Penemuan Hukum dan Anatomi dalam Penerapannya' (2011) 21 Jurnal Mimbar Hukum.

Gedalya Iryawan Kale, 'Syarat Kepailitan Sebagai Bentuk Perlindungan Hukum Debitor Dalam Undang-Undang Nomor 37 Tahun 2004' (2018). 6 Jurnal Kertha Semaya.

Luh Ayu Maheswari Prabaningsih, 'Pengaturan Insolvency Test Dalam Penjatuhan Putusan Pailit Terhadap Perusahaan' (2019) 7 Jurnal Kertha Semaya.

Marc Lampe, 'Mediation as An Ethical Adjunc of Stakeholder Theory' (2001) Journal of Bussines Ethics.

Ricardo Simanjuntak, 'Rancangan Perubahan Undang-undang Kepailitan dalam Pengacara (Komentar Terhadap Perubahan Undang-undang Kepailitan)' (2002) 17 Jurnal Hukum Bisnis.

Ricardo Simanjuntak, 'Relevansi Eksekusi Putusan Pengadilan Niaga dalam Transaksi Bisnis Internasional', (2003) 22 Jurnal Hukum Bisnis.

Sutan Remy Sjahdeini, 'Sejarah Hukum Kepailitan di Indonesia' (2001) 12 Jurnal Hukum Bisnis. 


\section{Karya Ilmiah}

Krista Yitawati, 'Analisis Asas Pemberian Manfaat dan Perlindungan yang Seimbang Antara Kreditor dan Debitor pada Pasal 2 Undang-Undang Nomor 37 Tahun 2004 Tentang Kepailitan Dan PKPU Mengenai Syarat-Syarat Pailit (Kajian Putusan Pailit PT Dirgantara Indonesia Dan PT Televisi Pendidikan Indonesia)' Tesis, (Universitas Sebelas Maret).

Syah Yannuar Ariefandi, 'Pembatalan Putusan Pailit Akibat Adanya Utang Yang Tidak Dapat Dibuktikan Secara Sederhana Dalam Perjanjian Kerjasama (Kajian Putusan Mahkamah Agung No. 704.K/Pdt.Sus/2012)' (2013) Artikel Ilmiah Hasil Peneitian Mahasiswa.

\section{Laman}

Amrizal, 'Pencegahan dan Pendeteksian Kecurangan Oleh Internal Auditor' http:/ / bpkp.go.id/public/upload/unit/investigasi/files/Gambar/PDF/ cegah_deteksi.pdf, diakses pada 19 Januari 2021.

Hikmahanto Juwana, 'Solusi Pascapemailitan PT DI', http://www.kompas.com/ kompas-cetak/0709/.18/opini/3836688.htm, diakses pada 02 Februari 2021

\section{Perundang-undangan}

Undang-Undang Nomor 37 Tahun 2004 tentang Kepailitan dan Penundaan Kewajiban Pembayaran Utang.

The Statutes of the Republic of Singapore, Companies Act (Chapter 50), Revised Edition 2006.

The Singapore Insolvency, Restructuring and Dissolution Act No. 40 of 2018.

How to cite: Clarita Stefanie, R. Kartikasari, Artaji, 'Pembatasan Kebebasan Beragama dalam Darurat Kesehatan Virus Korona di Indonesia: Perspektif HAM dan Islam' (2022) Vol. 5 No. 1 Media Iuris. 
--Halaman ini sengaja dibiarkan kosong-- 